\title{
KUALITAS PERKAWINAN INDIVIDU YANG MENIKAH TANPA PACARAN (COURTSHIP MODEL)
}

\author{
AlKhusna \\ Hepi Wahyuningsih \\ Universitas Isiam Indonesia
}

\begin{abstract}
This research aimed to compare quality of marriage between subjects who decided to engage in marriage without matching fiactor. Qualififative method was applied in this research. Five subjects were inwolve, having criteria such as: 1) married without dating process, 2) married not based on matching factor, 3) this is their first marriage and 4) already having child (ren).

Based on research findings it is concluded that religion or religiousily is the the basic reason for them in deciding $b$ get manied. The quallity of their marriage is influenced by adjustment along maniage, husband/wire (couple) evalution to each other and role distribution. Rolo distribution is considered as potential source for maniage conflict. Marriage conflict should overcome through communication and social support. It is surprisingly found that marriage conflicts which were well handle and cohesivity were able to strengthen marriage quality.
\end{abstract}

Key words: mamiage qualify, daling, couple evaluation

\section{Pengantar}

Kedekatan yang penuh cinta dan saling memahami sangat dipertukan dalam membina suatu hubungan, terutama hubungan dalam sebuah ikatan perkawinan. Belajar mencintai adalah suatu hal yang penting. Oleh karena itu Hunt (Tucker, 2000) menganjurkan bahwa setiap individu harus mempelajarinya dengan lebih serius jika ingin cintanya terus bersemal.

Keinginan untuk mendapatkan pasangan yang sesual dengan kriteria yang diinginkan agar bisa menuju kehidupan perkawinan yang berbahagia dan langgeng merupakan keinginan besar yang tentunya ingin dicapai oleh setiap individu yang hendak membina rumah tangga. Untuk maksud itulah usaha mengenal lebih jauh karakteristik serta sifat calon pasangan sangat diperlukan. Tujuannya lalah agar nanti ketika sudah menikah pasangan tersebut bisa mudah untuk saling memahami, saling menyesuaikan diri, dan sedapat mungkin menghindari konflik-konflik yang bisa terjadi akibat karakteristik pasangannya yang mungkin tidak sesuai dengan harapannya.

Salah satu cara menyeleksi calon pasangan yang kini banyak ditempuh ialah dengan pacaran atau dating. Hasil penelitian kualitatif yang dilakukan Hanifah (situs.kesrepro.info) untuk melihat definisi pacaran menurut remaja menunjukkan bahwa pacaran didefinisikan sebagai dua orang berbeda jenis keiamin saling menyukal, atau berkomitmen, kedekatan dua orang 
Sebagian besar masyarakat nampaknya meyakini bahwa pacaran merupakan awal yang tepat untuk menuju mahligai perkawinan yang bahagia yang dilandasi cinta, dan masa penjajakan mencari pasangan hidup. Sebagian orang yang ternyata memilih untuk menikah tanpa didahului oleh proses pacaran. Nampaknya mereka tidak terlalu terpengaruh oleh adanya keyakinan bahwa pacaran merupakan awal yang baik untuk menuju kehidupan perkawinan yang bahagia. Dengan alasan yang mereka miliki, mereka tidak memilih pacaran sebagai awal untuk menuju jenjang perkawinan.

Perkawinan tanpa didahului pacaran sebenarnya telah ada sejak dahulu. Perkawinan tanpa pacaran pada saat itu terutama dikarenakan faktor perjodohan yarng dilakukan oleh orangtua kedua pihak. Pada masyarakat tani tradisional, perkawinan seorang anak yang telah dianggap cukup usia untuk menikah ditentukan oleh orangtua atau anggota keluarga lainnya yang lebih tua. Anak tidak merriliki hak untuk menentukan sendiri calon pasangannya. Perasaan cinta atau suka d antara kedua calon pengantin tidak begitu dipertimbangkan (Shehan, 2003).

Seiain karena perjodohan yang dilakukan orangtua, perkawinan tanpa didahului pacaran bisa juga dikarenakan faktor lain, seperti karena alasan aturan agama yang diyakini tidak memperbolehkan pacaran atau dengan menggunakan perantara pihak-pihak tertentu, d mana pihak tersebut tidak mempunyai hak untuk memaksa dan hanya bertindak sebagai perantara dan keputusan terakhir tetap pada individu tersebut.

Berdasarkan wawancara awal pada beberapa individu yang menikah tanpa didahului pacaran terungkap bahwa awal mereka mengenal calon pasangannya serta sifat-sifatnya biasanya berasal dari informasi orangtua, guru, atau temannya. Perkenalan itu pun biasanya hanya berlangsung dalam waktu yang relatif singkat (bisa seminggu, sebulan, atau dua bulan), asalkan informasi sudah dianggap cukup dan ketika sudah tidak ada lagl keraguan d kedua belah pihak dan tanpa harus sering bertemu, mereka pun bisa langsung memutuskan untuk melangsungkan pemikahan. Begitu pulalah yang terjadi dalam pernikahan da'i muda yang terkenal dengan majelis dzikirnya Ustadz Arifin tham, yang menikahi istrinya hanya setelah dua kali berjumpa (Hidayatullah, November 2004).

Berdasarkan fenomena-fenomena tersebut d atas, peneliti tertarik untuk mengetahui kualitas perkawinan pada individu yang menikah tanpa didahului pacaran

\section{Tìnjauan Pustaka}

Pengertian Kualitas Perkawinan. Kualitas perkawinan ialah istilah umum yang sering dipakai oleh para penelitl untuk menitai secara luas suatu hubungan antar individu dalam sebuah perkawinan. Kualitas perkawinan mencakup kebahagiaan, kepuasan, serta stabilitas hubungan perkawinan. Istilah ini kini banyak digunakan oleh para ahli sosiologi keluarga (Shehan, 2003).

Menurut Scanzoni dan Scanzoni (Hendrix, 1997), kualitas perkawinan sebagai sebuah bentuk dimensi ekspresi dalam sebuah perkawinan memiliki tiga elemen, yaitu keterikatan, kasih sayang secara fisik, dan empati. Keterikatan bisa juga berarti hubungan emosional antar pasangan yang merasa saling memiliki dan sebagainya.

Lewis dan Spanier (Walton, 2000) menggunakan beberapa konsep umum untuk menjelaskan tentang kualitas perkawinan, seperti kepuasan perkawinan, kebahagiaan perkawinan, saling memahami peran masing-masing, penyelesaian konfllk dan komunikasi yang baik, serta penyesuaian difi antar pasangan. Kualitas perkawinan ialah istilah yang cakupanrya lebih luas daripada konsep-konsep lain tersebut. Meski demikian, penggunaan konsep-konsep umum tersebut secara 
sederhana juga dapat digunakan untuk menjelaskan tentang kualitas perkawinan.

Perkawinan yang berkualitas atau perkawinan yang sukses ialah perkawinan yang di dalamnya terdapat cinta dan kasih sayang, bisa memperoleh anak-anak yang sehat dan bahagia, kebersamaan yang erat, menimbulkan ketentraman emosi, hubungan seksual yang memuaskan, ketertarikan dan aktivitas yang sama dengan pasangan, kebebasan untuk berkembang secara personal, ketercukupan secara ekonomi, kesamaan nilai dan keyakinan, serta penerimaan dari lingkungan (Shehan, 2003).

Dari penjelasan di atas dapat diketahui bahwa kualitas perkawinan jalah sebuah gambaran tentang kehidupan perkawinan pasangan suami istri dalam membina sebuah keluarga atau rumah tangga yang berkaitan dengan berbagai faktor dan aspek, baik lahlrataupun batin.

Faktor-faktor Yang Mempengaruhi Kualitas Perkawinan. Berdasarkan kajian dari beberapa literaturyang ada, faktor-faktor yang mempengaruhi kualitas perkawinan sepasang suami istri setidaknya dapat dimasukkan dalam tiga kelompok besar, yaitu:

a Karakteristik dan Latar Belakang Personal dan Pasangan

Beberapa hasil penelitian telah menemukan bahwa karakteristik serta latar belakang atau keblasaan personal dan pasangan dapat mempengaruhi kualitas perkawinan. Menurut Lewis dan Spanier (Walton, 2000), kesamaan faktor yang diperoleh sebelum menikah (usia, pendidikan, kelas sosial, suku, dan agama) akan meningkatkan kualitas perkawinan yang lebih baik. Individu yang menikah dengan pasangan dari agama yang sama terbukti memiliki kepuasan perkawinan yang lebih tinggi jika dibanding dengan pasangan yang berbeda agama (Ortega dkk, dalam Shehan, 2003). Demikian pula status sosial ekonomi yang tinggi mempunyai hubungan positif dengan kualitas perkawinan (Kurdek, Larson dan Hotman, dalam Shehan, 2003).

Selain agama dan status sosial ekonomi ${ }_{r}$ karakteristik serta kebiasaan yang berpengaruh dalam kualitas perkawinan ialah ras atau suku. Perbedaan ras atau suku dapat menjadikan kualitas perkawinan rendah. $\mathrm{Hal}$ ini karena masing-masing ras atau suku tentu memiliki karakteristik yang berbeda dengan ras atau suku yang lain. Hanya saja, jika masing-masing pasangan memiliki identitas ras yang baik, yaitu mau menerima kekurangan dan kelebihan ras yang lain, maka mereka memiliki kualitas perkawinan yang tinggi (Leslie, dkk, 2004). Begitu juga pengalaman-pangalaman masa lalu, terutama terkait dengan perkawinan orangtua juga berpengaruh pada kualitas perkawinan. Hubungan yang baik dengan orangtua yang memiliki perkawinan yang bahagia, akan memungkinkan individu untuk memiliki kualitas perkawinan yang tinggi (Larson dan Holman dalam Shehan, 2003).

Secara garis besar, Shehan (2003) membuat rangkuman yang menjelaskan tentang faktor karakteristik personal serta latar belakang yang senantiasa berkaitan dengan kualitas perkawinan sebagai berikut:

1) Faktor yang senantiasa berkaitan dengan tingginya kualitas perkawinan, y aitu: usia perkawinan yang lebih tua, pendidikan yang tinggi, status ekonomi yang mapan, status pekerjaan yang tinggi, kesehatan fisik dan mental yang baik, hubungan perkawinan orangtua yang baik, dan penerimaan pasangan di antara keluarga dan teman.

2). Faktor yang kadang-kadang berkaitan dengan kualitas perkawinan yang rendah, yaitu: perbedaan sosial ekonomi, perbedaan agama, dan perbedaan ras.

3). Faktor yang senantiasa berkaitan dengan kualitas perkawinan yang rendah, yaitu : pengalaman hidup 
tanpa ikatan perkawinan yang lalu, pengalaman perkawinan yang lalu, dan ras.

b. Kondisi Yang Mengiringi Kehidupan Perkawinan

Dukungan serta penerimaan dari teman atau komunitas di mana pasangan itu tinggal ternyata juga berpengaruh pada kualitas perkawinan. Semakin besar dukungan serta penerimaan dari ternan atau lingkungan di mana mereka tinggal, maka semakin tinggi pula kualitas perkawinan mereka (Shehan, 2003). Kehadiran anak juga berpengaruh pada kualitas perkawinan. Beberapa hasil stud: menunjukkan bahwa pasangan yang hidup dalam sebuah perkawinan mengalami penurunan kualitas perkawinan setelah kelahiran anak (Belsky \& Gleen, dalam Shehan, 2003). Pada umumnya, kualitas perkawinan menurun saat kehadiran anak pertarna, kemudian mengalami penurunan lagi ketika anak telah mencapai usia sekolah, dan semakin rendah ketika anak telah masuk usia remaja (Menaghan ; White dan Booth dalam Shehan, 2003). Belsky (Shehan, 2003) menyatakan bahwa penurunan kualitas perkawinan akibat kehadiran anak terjadi karena interaksi antara suami istri mengalami perubahan. Jika sebelum memiliki anak, istri lebih sering mernberi perhatian kepada suami, namun setelah memiliki anak pehatiannya lebih tertuju pada anak.

c. Proses Interaksi yang Terjadi Dalam Perkawinan

Perkawinan merupakan penyatuan antara dua individu yang berkomitmen menjalani hidup bersama. Sebuah perkawinan tidak akan lepas dari sebuah proses interaksi. Proses interaksi yang terjalin antara suami dan istri merupakan salah satu faktor yang dapat mempengaruhi kehidupan perkawinan mereka.

Baeder d]kk (2004) menyatakan bahwa ada tiga proses interaksi antar pasangan yang mempengaruhi kualitas dalam sebuah perkawinan, yaitu:

1). Interaksi yang sifatnya positif (positivity)

Interaksi dalam bentuk ini biasa dikaitkan dengan kualitas perkawinan yang tinggi. Interaksi ini meliputi: sering menghabiskan waktu berdua, mengembangkan identitas pribadi dalam hubungan yang mereka bangun, keterbukaan atau kedekatan satu sama lain, rnenunjukkan emosi yang positif, perilaku yang menunjukkan rasa cinta dan kasih sayang (bermesraan, saling membelai), dan perilaku yang saling mendukung.

2). Interaksi yang sifatnya negatif (negativity)

Perilaku ataџ emosi yang mengarah pada interaksi yang sifatnya negatif biasa dikaitkan dengan kualitas perkawinan yang rondah. Interaksi negatif ini seperti: pola-pola hubungan yang negatif, balk ketika terjadi konflik maupun dalam kehidupan sehari-hari (sering marah, takut, sedih, dan muak terhadap pasangan), perilaku-perilaku negatif yang diekspresikan secara terbuka (memaksa, marah yang meledak-ledak, agresi, banyak menuntut), dan perilaku sering mengkritik. Selain itu juga peritakuperilaku yang tidak menyenangkan seperti penolakan, tidak responsif, saling merendahkan, dan saling menjauhi.

3). Interaksi yang berkaitan dengan kognisi (cognitions)

Interaksi yang sifatnya kognisi ini tidak dinampakkan dalam perilaku. In

teraksi kognisi lebih mengarah pada pandangan serta anggapan anggapan yang dikembangkan oleh masing-masing pasangan terhadap pasangannya.

Domain Kualitas Perkawinan. Olson dkk (Shamai dan Lev, 1999) menilai sebuah kualitas perkawinan dengan melihat delapan area yang terkait dengan sikap individu 
terhadap diri mereka sendiri dan perasaan mereka terhadap pasangannya. Delapan area yang ditaksir tersebut lalah:

a. Kepribadian, mencerminkan penyesuaian terhadap pasangan dan kepuasan terhadap perilaku pasangan.

b. Komunikasi, mencerminkan sikap dan perasaan individu terhadap peran komunikasi dalam pemeliharaan hubungan.

c. Resolusi konflik, menilai sikap tentang konflik hubungan dan kenyamanan dengan cara yang ditempuh untuk menangani konflik tersebut.

d. Manajemen keuangan, memusatkan pada sikap dan perhatian tentang cara yang ditempuh dalam pengaturan masalah ekonomi di dalam hubungan suami istri.

e. Aktivitas kesenangan, menilai pilihan individu dan kesepakatan antar pasangan tentang penggunaan waktu untuk sebuah aktifitas kesenangan.

f. Hubungan seksual, mencerminkan perasaan dan perhatian individu tentang peran kasih sayang dan seksualitas dalam hubungan perkawinan.

g. Anak-Anak dan perkawinan, mencerminkan suatu konsensus mengenai pengambilan keputusan untuk memiliki dan mengasuh anak serta kepuasan dengan peran orangtua yang digambarkan.

h. Keluarga dan teman-teman, menilai perasaan dan perhatian tentang hubungan dengan famili, keluarga pasangan, dan teman.

Model Penyeleksian Pasangan.

Setidaknya ada tiga model memilih atau menyeleksi pasangan yang terjadi di masyarakat, yaltu model tradisional, model dengan saling mengenal, dan model masa sekarang (Shehan, 2003)

a. Model Tradisional (Traditional Agrarian Model)

Pada masyarakat tani tradisional, perkawinan seorang anak yang telah dianggap cukup usja untuk menikah ditentukan oleh orang tua atau anggota keluarga lainnya yang lebih tua. Siapa pasangan nikah anak tersebut juga ditentukan ofeh mereka. Anak tidak memiliki hak untuk menentukan sendiri calon pasangannya. Perasaan clnta atau suka di antara kedua calon pengantin tidak begitu dipertimbangkan. Pada masa tersebut blsa jadi antara calon pengantin laki-laki dan calon pengantln perempuan belum pernah bertemu sama sekali.

b. Model Saling Mengenal (Courtship Moden)

Pada model ini, remaja lebih diberikan kebobasan untuk menentukan sendiri calon pasangannya. Pengawasan terhadap hubungan mereka juga tidak seketat dalam model tradisional. Sepasang muda mudi dalam model ini bisa lebih sering berjumpa, namun tetap harus ada orang ketiga, yang biasanya ialah ternan perempuan remaja putri yang umurnya lebih tua darinya. Salah satu hal yang menarik dari model ini ialah bahwa pihak laki-laki tidak diperkenankan mendatangi pihak perempuan kecuali jika dia memang telah diundang untuk datang oleh lbu perempuan tersebut. Selain itu, seorang laki-laki tidak diperkenankan menjalin hubungan dengan seorang perempuan kecuali ia telah terlebih dahulu meminta izin pada orangtua perempuan tersebut. Dalam model seleksi pasangan ini, kriteria pemilihan calon pasangan tidak lagi terturnpu pada fakor ekonomi, namun lebih berdasar pada penarnpilan fisik, kepribadian, serta cinta.

c. Model Masa Kini (Contemporary Model) Adapun yang dlmaksud model penyelesian pasangan masa kini ialah model penyeleksian yang pada saat ini banyak dipraktekkan oleh remaja-remaja di Amerika dan Negara-negara Barat lainnya. Pada model ini, seorang anak rnemiliki kebebasan penuh untuk menentukan sendiri pasangannya sedangkan orangtua hanya sekedar memberi support atas pilihan anaknya. Sepasang remaja putra dan putri bebas 
untuk sering berjumpa tanpa pengawasan dari siapapun dan mereka pun memiliki lebih banyak kesempatan untuk berdua-duaan di tempat tempat umum. Model pemilihan pasangan inilah yang klni dimaksud dengan istilah dating atau pacaran. Seperti yang dikemukakan oleh Harris (Olson \& DeFrain, 2003) bahwa batasan pengertian pacaran adalah : mengarahkan pada sebuah keintiman, hubungan yang lebih dari sekedar persahabatan, mengarah pada ketertarikan yang sifatnya romantis, cenderung untuk mengekspresikan cinta dan romantisme semata-mata sebagai kesenangan belaka, okspresi cinta dalam pacaran sering dimaksudkan dengan adanya hubungan fisik, pasangan yang menjalin pacaran sering menjauhkan diri dari hubungan pertemanan intim yang lain, banyak membutuhkan waktu dan energi, dan peluang untuk saling mengenal karakterorang lain.

Dalam penelitian ini, yang disebut sebagai menikah tanpa pacaran adalah model penyeleksian pasangan courtship model yaitu adanya kebebasan individu untuk menentukan sendiri calon pasangannya, tetapl dalam seliap pertemuan calon pasangan tetap harus ada orang ketiga yang mengawasi interaksi calon pasangan, yang biasanya ialah teman perempuan remaja putri yang umumya lebih tua darinya.

\section{Metode Penelitian}

Desain dan Fokus Penelitian. Penelitian ini dilakukan dengan menggunakana pendekatan kualitatif. Penelitian kualitatif bertujuan untuk memperoleh pemahaman yang otentik mengenai orang-orang, sebagaimana dirasakan orang-orang bersangkutan. Metode kualitatif digunakan untuk mengungkap sifat pengalaman seseorang dengan fenomena tertentu. Selain itu, metode kualitatif juga dapat digunakan untuk mengungkap sesuatu di balik fenomena yang sedikit dan belum diketahui. Metode ini dapat juga digunakan untuk mendapatkan wawasan tentang sesuatu yang baru sedikit diketahul (Strauss dan Corbin, 2003).

Adapaun fokus peneitian ini ialah kualitas perkawinan individu yang menikah tanpa pacaran. Menikah tanpa pacaran adalah model penyeleksian pasangan courtship model yailu adanya kebebasan individu untuk menentukan sendiri calon pasangannya, tetapi dalam seliap pertemuan calon pasangan tetap harus ada orang ketiga yang mengawasi interaksi calon pasangan, yang biasanya lalah teman perempuan remaja pulri yang umurnya lebih tua darinya.

Subyek. Subyek penelitian ini memiliki adalah suami atau istri yang menikah tanpa pacaran, mentkah bukan karena faklor perjodohan yang dipaksakan, perkawinan yang dijalanl adalah perkawinan yang pertama, dantelah memilikl anak.

Metode Pengumpulan Data. Metode yang digunakan untuk pengumpulan data dalam penelitian Ini ialah melode wawancara mendalam. Arikunto (1998) mengartikan wawancara sebagai sebuah dialog yang dilakukan oleh pewawancara (interviawer) untuk memperoleh informasi dari terwawancara (interviewee). Wawancara kualitatif dilakukan bila peneliti bermaksud untuk memperoleh pengetahuan tentang makna-makna subjektif yang dipahami individu berkenaan dengan topik yang diteliti, dan bermaksud melakukan eksplorasi terhadap isu tersebut, suatu hal yang tidak dapat dilakukan melalui pendekatan lain (Banister dkk dalam Poerwandari, 2001).

Proses wawancara dilakukan dengan mengacu pada pedoman wawancara (guide interview) yang berlsi pertanyaanpertanyaan utama mengenal aspek-aspek kualitas perkawinan berdasarkan teorl yang ada. Tujuan penggunaan pedoman wawancara ini ialah agar wawancara yang dilakukan lebih terfokus dan bisa mendapatkan data yang mendalam.

Adapun pedoman wawancara yang digunakan dalam penelitian ini iaiah: 
1. Bagaimana penyesuaian yang dilakukan terhadap pasangan?

2. Bagaimana perllaku pasangan Anda selamaini?

3. Bagaimana komunikasi Anda dengan pasangan dalam menjaga hubungan?

4. Bagaimana Anda memelihara hubungan dengan pasangan?

5. Bagaimana Anda dan pasangan menyikapl masalah hobi atau kesenangan masing-masing?

6. Bagaimana Anda dan pasangan Anda mengatasi konflik yang terjadi dalam perkawinanAnda?

7. Bagalmana hubungan perkawinan Anda dengan keluarga, teman-teman, dan masyarakat sekitartempatAnda tinggal?

Analisis Data. Data yang diperoleh dianalisis dengan content analysis. Ada tiga tahap yang harus dilakukan dalam analisis dengan content analysis, yaitu: open coding, axial coding, dan selective coding. Dalam open coding, peneliti mencari tema-tema dari hasil wawancara dengan subyek penelitian. Setelah proses open coding selesai, kemudian dilakukan axial coding, yaitu mengelompokkan tema-tema ke dalam subkategori dan kategori. Proses analisis yang terakhir adalah selective coding, yaitu membuat model/mencari hubungan antar subkategori ataupun kategori.

\section{Hasil Penelitian}

Berdasarkan hasil penelitian yang telah dilakukan didapatkan gambaran tentang bagalmana kehidupan perkawinan yang dirasakan oleh para responden penelitian.

a. Agama/Spiritualitas.

Alasan yang dipakai para responden untuk menlkah tanpa pacaran pada umumnya lalah karena mereka meyakini bahwa pacaran tidak diperkenankan oleh agama mereka. Menikah adalah pengamalan agama. Alasan agama inilah yang menjadi alasan utama semua subjek dalam penelitian ini untuk memutuskan menikah tanpa pacaran. "ya.. saya kira. Saya prinsipnya pake prinsip agama ya . karena agama saya Islam. Karena Islam mengatur sedemikian rupa bagaimana cara bergaul dalam Islam, ye itu saya taati.. ketika tidak boleh berdua-duaan di tempat sepi..saling bersentuhan.. harus menjaga pandangan.. ya .itu insyaallah saya lakukan. ya yang jelas seperti itu". (W1 L, 50-57)

b. Penyesuaian dengan pasangan.

Responden pertama dan kedua menyatakan bahwa saat awal menikah, mereka senantiasa melihat hal-hal yang baik dari pasangannya dan juga senantiasa mencoba untuk menunjukkan perilaku-perilaku yang baik pula. Begitu pula sebenarnya responden ketiga yang memang saat awal-awal nikah berjauhan dengan pasangannya, karena ia di Semarang sedangkan pasangannya di Jogjakarta. Ketika bertemu merekapun menunjukkan sikap dan perilaku yang menyenangkan. Sedangkan responden keempat mencoba untuk menyesuaikan diri dengan sering mengikuti hobi dan kesenangan bersama pasangan. Responden kelima melakukan penyesuaian dirl dengan sering berdiskusi. Selain itu para responden tersebutjuga melakukan penyesuaian diri dengan melakukan berbagai aktifitas bersama-sama. Selanjutnya penyesuaian yang juga mereka lakukan ialah dengan saling memahami dan menyadari serta menerima kekurangan.

"ya saling memahami.. betul.. betul.. bila saya ada kekurangan.. termasuk anu ya... saya pribadi ada hal-hal yang sedikit berbeda dengan yang diharapkan .. (W1,A, 150-153)"

\section{c. Penilaian perilaku pasangan.}

Responden secara umum menilai bahwa perilaku pasangan mereka cukup bagus dan tidak banyak yang menjadikan masalah. Meskipun para responden juga menilai bahwa tidak semua peritaku 
pasangan sesuai dengan yang diharapkan dan sempat juga menjadi konflik, namun mayoritas mereka menganggap bahwa perilaku tersebut masih dalam taraf yang normal dan masih wajar sehingga tidak perlu dijadikan sumber pertentangan yang serius, karena selain mereka menganggap hu sebagai hal yang manusiawi mereka juga menyadari bahwa mereka juga punya kekurangan.

"setelah nikah.. ya.. terus terang ada juga yang temyata kok tidak..tidak semuanya sesuai harapan gitu... is kadang-kadangjadi konflikjuga .. tidak semuanya seperti itu ... (W2,L, 124129)"

\section{d. Komunikasi dalam perkawinan.}

Semua responden menyadari bahwa komunikasi merupakan sesuatu hal yang penting dalam sebuah perkawinan. Komunikasl yang dibangun dalam perkawinan responden di antaranya ialah dengan saling terbuka, memahami maksud, menjaga untuk tidak memerintah, menghargat dan memperhatikan, serta dengan mengagendakan pertemuan khusus untuk saling diskusi, ataupun bahkan dengan menggunakan panggilanpanggilan mesra dan memutar $C D$ pemikahan mereka.

"ya sangat penting sekali.. ya komunikasi itu satu hal yang sangat penting.. bukan hal yang utama tapi sangat penting sekali... soalnya dalam perkawinan lu kan jika tidak bisa mengkomunikasikan apa yang kita inginkan, apa yang kita rasakan maka.. ee... mungkln yang terjadi adalah kesalahpahaman.. pasangan kita ga' ngerti kalo kita diam aja .. jadi ya malah bisa muncul kesalahpahaman .. (W2,J, 134-141)"

\section{e. Konflik dalam perkawinan.}

Kehidupan perkawinan responden pun diakui pernah mengalami konflik. Konflik yang muncul dalam perkawinan mereka disebabkan oleh faktor sikap atau perilaku yang saling ingin menang sendiri, hobi yang berbeda, pengasutian anak, dan juga ada yang muncul karena faktor dari luar urusan rumah tangga pasangan, yaitu berkailan dengan urusan keiuarga besar masing-masing pasangan. Meskipun jika sedang terjadi konflik kadang hubungan atau komunikasi menjadi semakin renggang karena saling diam atau bahkan pergi menghindari pasangan, namun selama ini semua itu bisa dlałas| dengan berbagai cara yang mereka terapkan, seperti dengan saling meminta maat ketika berbua: salah, membangun kembali komunikasi melalul aktivitas yang biasa dilakukan bersama, saling mengalah, cepat menyadarl, dan mencarl waktu yang tepat untuk meredakan hingga mendiskuslkan bersama konflik yang telah terjadi yang kemudian mencoba menjadikannya pelajaran untuk leblh baik lagi ke depannya. Konflik yang terjadl tersebut tidak pemah terjadi dalam waktu yang lama.

ya kalau kecil-kecil jeias kayak masalah mendidik anak tw ... misalnya ada sedikit ketidak anu... tapl kan bisa ter anu.. masalah sikap itu.. ada perbedaan.. tapikan kemudian bisa temetralisir... (W1, A,393-396)

jya.. kadang seperti itu. Isteri saya kadang pengennya sekali-kali mbok ya.. mbantui kalo pas di rumah. misalnya kaio pas di rumah kan karena dari iuar dah capek ya.. di rumah nyante.. nyante-nyante aja.. ya bacabaca buku.. atau nonton tv.. isteri saya.. mbok ya mbantu. saya in: capek gltu... tapi lama-lama saya bisa ngerasakan.. $\bullet$.. wah capek juga ya kayak gitu .. (W2,L,333-340)

\section{f. Pembagian peran dalam porkawinan.} Hasil wawancara menunjukkan bahwa peran antara suami istri dalam perkawinan responden secara umum 
tidak diatur dengan atu ran yang mengikat. Meskipun tetap mengarahkan suami berperan utama sebagai pencari nafkah sedang istri lebih berperan untuk urusan rumah, terutama mengasuh anak, namun peran dalam perkawinan mereka bisa pula didasarkan pada kesepakatan atau berdasar kesadaran masing-masing, sehingga adakalanya urusan rumah tangga jug a diperankan oleh kedua pihak. Juga tidak ada hambatan bagi pihak istri untuk membantu mencari nafkah atau mengembangkan dirinya di luar rumah. Adapun masalah pengaturan keuangan, semua responden menyatakan pernyataan yang sama bahwa untuk pengelolaan semua keuangan dalam keluarga, pihak istrilah yang menanganinya. Dalam mendidik dan mengasuh anak, perannya bukan hanya dibebankan kepada istri, namun suami pun kadang ikut berperan. Bahkan sering peran mendidik anak tersebut digilir antara istri dan suami, seperti yang diungkapkan responden pertama, kedua dan keempat.

untuk peran...peran.. kita tidak kemudian mengatur saya harus bagaimana dan suami saya harus bagaimana.. tidak.. jadi berdasarkan kesadaran masing-masing aja.. misalnya saya saat ini saya bekerja.. ya saya harus sadar saya juga seorang isteri.. saya seorang bu... saya memang masih mempunyai kewajiban untuk megerjakan pekerjaan rumah.. jadi seperti itu .. tidak terus diatur _ jadi lebih ke kesadaran pribadi lah!! (W1, J,84-94)

g. Kohesivitas dalam perkawinan.

Untuk urusan kesenangan bersama, beberapa responden menyatakan bahwa mereka memiliki berbagai kesenangan bersama. Kesenangan bersama tersebut sering digunakan oleh para responden untuk saling mengisi waktu bersama. Hal menarik yang ditemukan dalam penelitian ini ialah bahwasannya para responden memiliki tempat-tempat tujuan tertentu untuk dikunjungi bersama. Sebagian besar tempat-tempat tujuan tersebut bersifat agamis, terutama masjid-masjid besar yang ada di Jogjakarta. Hanya responden keempat yang menyatakan bahwa tempat yang sering mereka kunjungi untuk bersama ialah mall.

karena kita sama-sama seneng berpetualang jadi ya.. dengan berpetualang itu.. sebelum berangkat ya.. kita ngomong sama temen-temen di sini. Kita naik gunung bersama .. ittu juga bentuk komunikasi .. dan setelah nikah juga. Dengan anak... anak masih kecil itu saya ajak ke merapi itu juga pernah .. (W2,A,230*236)

Tapi kalo rekreasi setiap hari seperti.. saya kira rekreasi yang benar itu berkunjung ke keluargakeluarga itu (yang menikah sudah lama).. itu rutin.. seminggu bisa dua kali.tiga kali..(W1, M, 1094-1098)

\section{h. Dukungan Sosial}

Perkawinan juga melibatkan keluarga besar dari kedua individu yang menyatu tersebut dan bahkan masyarakat luas. Dalam penelitian ini diketahui bahwa perkawinan semua responden direstui oleh orang tua kedua pasangan. Hubungan perkawinan mereka dengan orangtua mereka juga terjalin dengan bakk, bahkan ada yang terjalin semakin bakk, sebagaimana pada perkawinan responden kedua dan kelima. Begitu pula hubungan perkawinan mereka dengan lingkungan dan teman-teman terjalin dengan baik.

hubungannya baik.. bahkan hingga saat ini kami kan belum punya rumah sendiri.. tapi disuruh tinggal sama mereka dulu .. ( $W / 1, J, 218-220)$

wah sekarang malah jadi semakin akrab ya.. karena orangtua saya sering ke sana, yang sana juga sering ke sini..jadi akrablah... nggak masalah kalau keluarganya.. semakin eratlah .. (W1 L, 618-621) 


\section{Pembahasan}

Berdasarkan gambaran kehidupan perkawinan yang didapatkan terse but, dibuat model yang dapat menggambarkan kualitas perkawinan. Gambaran model tersebut ialah sebagai berikut.

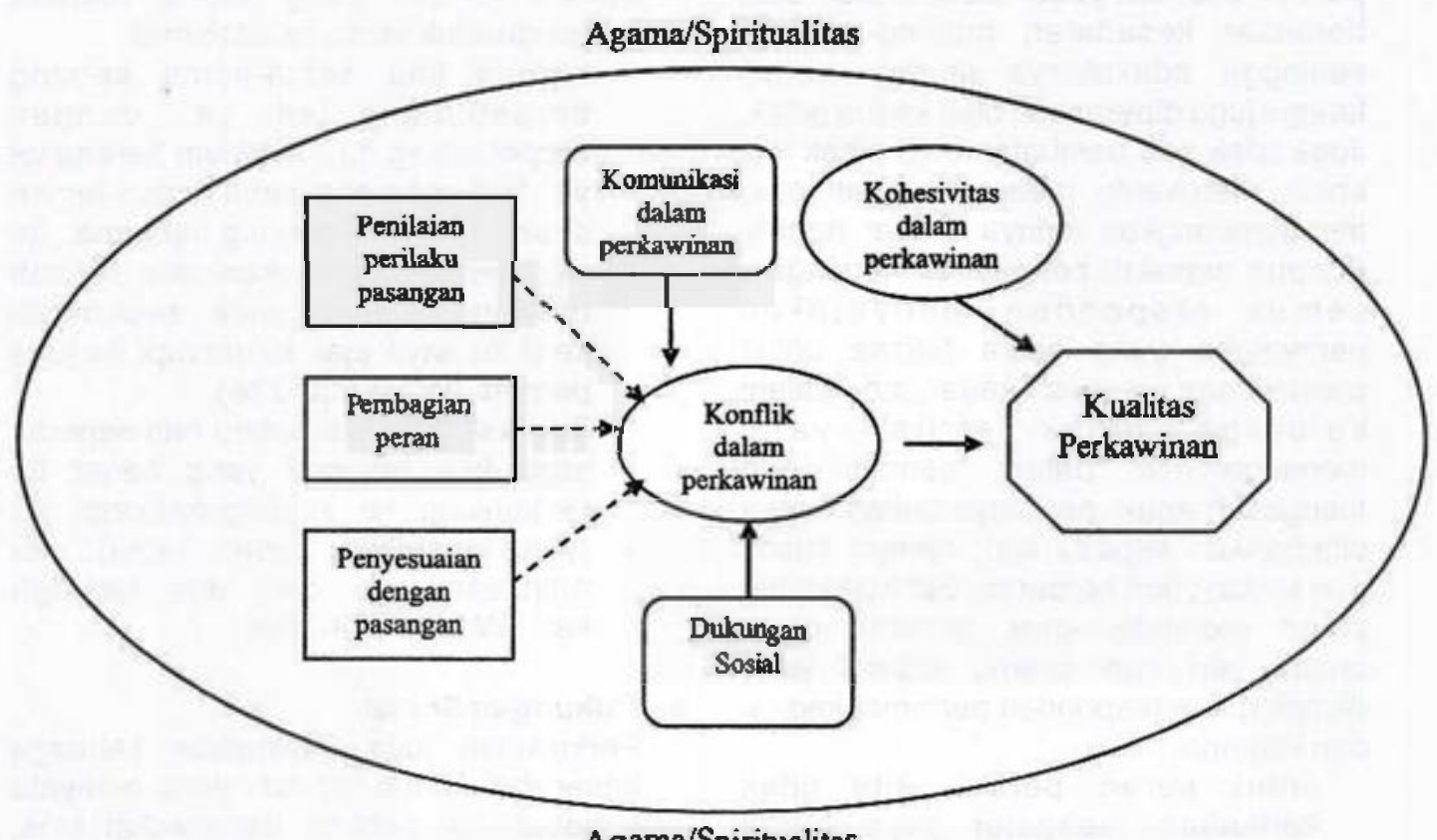

Agama/Spirinualitas

Gambar 1.

Model Kualitas Perkawinan Pasangan Yang Menikah Tanpa Pacaran (Courtship Model)

Gambar di atas menunjukkan bahwa satu hal yang tidak bisa dilepaskan dari sebuah perkawinan lalah peranan faktor agama. Menyadari bahwa manusia adalah makhluk yang terbatas kemampuannya, maka suatu saat pasti akan menyerahkan segala sesuatu yang di luar kemampuannya kepada Dzat yang maha kuasa tersebut (Walgito, 1984). Keyakinan kepada Tuhan inilah yang akan semakin meningkatkan penerimaan individu terhadap segala yang ia dapatkan dalam kehidupan perkawinannya yang kemudian akan menjadi bekal untuk menangani konflik yang terjadi dan peningkatan hubungan dengan pasangan. Lambert dan Dollahite (2006) dalam penetitiannya menemukan bahwa religiusitas berpengaruh dalam proses penyelesaian konfik pasangan suami istri.

Konflik yang muncul dalam perkawinan dapat terjadi karena penilaian terhadap pasangan, penyesuaian dengan pasangan, dan pembagian peran dalam perkawinan. Hasil-hasil penelitian menunjukkan bahwa jika pasangan suami istri menilai adanya ketidakadilan pembagian peran dalam rumah tangga, maka akan timbul konfilik yang kemudian akan menurunkan kualitas perkawinan (Frisco \& Williams, 2003). Konflik yang muncul dalam perkawinan responden disebabkan oleh faktor sikap atau perilaku yang saling ingin 
menang sendiri, hobi yang berbeda, pengasuhan anak, dan juga ada yang muncul karena faktor dari luar urusan rumah tangga pasangan, yaltu berkaitan dengan urusan keluarga besar masing-masing pasangan.

Meskipun jika sedang terjadi konflik kadang hubungan menjadi renggang karena saling diam atau bahkan pergl menghindari pasangan, namun selama ini semua itu bisa diatasi dengan berbagal cara yang mereka terapkan, seperti dengan saling meminta maaf ketlka berbuat salah, membangun kemball komunikasi melalui aktifitas yang blasa dilakukan bersama, saling mengalah, cepat menyadari, dan mencari waktu yang tepat untuk meredakan hingga mendiskusikan bersama konflik yang telah terjadl yang kemudian mencoba menjadikannya pelajaran untuk lebih baik lagi ke depannya. Konflik yang terjadi tersebut tidak pernah terjadi dalam waktu yang lama. Berkaitan dengan saling meminta maaf ketika terjadi konflik, hasil penelitian Paleari dkk (2005) menunjukkan bahwa memaafkan dalam perkawinan merupakan prediktor bagl kualitas perkawinan pasangan suami Istri.

Seperti telah disebutkan di awal, konflik dalam perkawinan responden juga dapat diatasi karena kemudian mereka kembali menjalin komunikasi yang baik. Hal ini dikarenakan semua responden menyadari bahwa komunikasi merupakan sesuatu yang penting dalam sebuah perkawinan. Komunikasi yang dibangun dalam perkawinan responden di antaranya ialah dengan saling terbuka, memahami maksud pasangan, serta dengan mengagendakan pertemuan khusus untuk saling diskusi, ataupun bahkan dengan menggunakan panggilan-panggilan mesra dan memutarCD pernikahan mereka.

Kemampuan menangani konflik yang dilakukan responden tersebut menunjukkan bahwasannya mereka memiliki kematangan emosi dan pikiran. Orang yang matang emosinya akan dapat berfikir secara objektif, sabar, penuh pengertian, toleransi, tidak mudah mengalami frustasi, dan mempunyai tanggung jawab yang baik (Walgito, 1984).
Dengan demikian, perkawinan yang tidak akan pernah lepas dari berbagai permasalahan tersebut akan dapat dihadapi dengan bijak dan penuh tanggung jawab serta tetap mampu terjalin dengan langgeng dan senantiasa dalam situasi harmonis.

Perkawinan responden juga melibatkan keluarga besar dari kedua individu yang menyatu tersebut dan bahkan masyarakat luas. Dalam penelitian ini diketahui bahwa perkawinan semua responden direstui oleh orang tua kedua pasangan. Hubungan perkawinan mereka dengan orangtua mereka juga terjalin dengan baik, bahkan ada yang terjalin semakin baik, sebagaimana pada perkawinan responden kedua dan kelima. Begitu pula hubungan perkawinan mereka dengan lingkungan dan teman-teman terjalin dengan baik. Mueller (2006) menemukan bahwa dukungan soslal merupakan conflict buffor dalam perkawinan. Ketika terjadi konflik pasangan suami istri, ternyata dukungan soslal mampu membantu pasangan suami istri menyelesaikan konflik perkawinan tersebut sehingga kualitas perkawinan menjadi baik.

Kesenangan juga dilakkan oleh responden dengan pasangannya untuk saling mengisi waktu bersama. Hal menarik yang ditemukan dalam penelitian ini lalah bahwasannya para responden memiliki tempat-tempat tujuan tertentu untuk dikunjungi bersama. Sebagian besartempattempat tujuan tersebut bersifat agamis, terutama masjid-masjld besar yang ada di Jogjakarta. Hanya responden keempat yang menyatakan bahwa tempat yang sering mereka kunjungi untuk bersama ialah mall. Sprecher dkk (1995) menemukan bahwa kohesivitas atau melakukan aktlvitas bersama berasosiasi dengan kepuasan dalam perkawinan.

\section{DAFTAR PUSTAKA}

Alsa, A 2003. Pendekaten Kuantilatif \& Kualitatif Serta Kombinasinya Dalam Penelitian Psikoiogi, Yogyakarta: Pustaka Pelajar 
Arikunto, S. 1998. ProsedurPenelitian (suatu pendekatan praktek), edisi revisi $\mathrm{N}$, Jakarta: Rineka Cipta.

Basri, H. 2002. Keluarga Sakinah, Tinjauan Psikologi dan Agama. Yogyakarta: Pustaka Pelajar.

Basyir, A A 2000. Hukum Perkawinan Islam, Yogyakarta: UII Press.

Bradbury, T, Fincham, F.D., \& Beach, S.R.H. 2000. Research On The Nature and Determinants of Marital Satisfaction: A docade in review, Journal of Marriage and the Family Volume 62; Minneapolis; Nov 2000, hal $964-980$

Frisco, M.L and Williams, K. 2003. Percieved Houswork Equity, Marital Happiness, and Divorce in DualEarner Housholds. Journal of Family issues, 24, 1, 51-73.

Hadiwardoyo, P. 1991. Perkawinan Menurut Islan dan Katolik; implikasinya dalam kawin campur, cetakan kedua, Yogyakarta: Kanisius.

Hendrix, L. 1997. Quality and Equality $h$ mariage: A cross-cultural viow, Cross-Cultural reseach; Thousand Oaks, Volume 31, Aug 1997, hal 201-225.

Lambert, N.M and Dollahite, D.C. 2006. How Religiosity Helps Couples Prevent, Resolve, and Overcome Marital Conflict. Family Relations, 55,4 , 439449

Leigh, A.L., \& Bethany, L. L, 2004, Marital quality of African American and white partners in interracial couples, Jurnal of Personal Relationships, December 2004, vol. 11, no. 4, hal 559-574(16)

Menchaca, D., \& Dehle, C. 2005. Marital Quality and Physiological Arousal:
How Do I Love Thee? Let My Heartbeat Count the Ways, American Journal of Family Therapy, February 2005, vol. 33, no. 2, hal. $117-130(14)$

Moleong, J.L. 2002. Motodologi Penelitian Kualitatif, Bandung : PT Remaja Rosdakarya.

Mueller, G.P (2006). Conflict Buffers and Marital Satisfaction: On the Effects of Different Forms of Social Support. Joumal of Happiness Studjes, Vd 7, 4, 499-515

Mulyana. 2000. Penelitian Kualitatif Paradigma Baru llmu Komunikasi dan Ilmu Sosial lainnya, Bandung: PT Remaja Rosdakarya.

Olson, D. H., \& DeFrain, J. 2003. Marriage and Families; Intimacy, Diversity, and Strengths, fourth edition, New York: McGraw-Hill. Inc

Paleari, F.G, Regalia, $C$, and Fincham, F, 2005. Marital Quality, Forgiveness, Emphaty and Rumination: A Longitudinal Analysis. Personality and Social Psychology Bulletin, Vol $31,3,368-378$

Poerwandari, K 2001. Pendekatan Kualitatif Untuk Penelitian Perilaku Manusia, Jakarta: LPSP3 Fakultas Psikologi Ul.

Prawiroharmidjodjo, R.S. 1994. Pluralisme Dalam Perundang-undangan Perkawinan di Indonesia, Surabaya: Airlangga University Press

Shehan, C. L. 2003. Marriage and Families, second edition, Pearson Education, Inc

Sholeh UG. 2005. Kitab Undang-undang Hukum Pacaran (KUHP). Yogyakarta: Amorbook. 
Sprecher, S., Metts, S, Burleson, B, Hatfield, E Thompson, A. 1995. Domains of expressive interaction in intimate relationships: Associations with satisfaction and commitment. Family Relations. 44, 2,203

Suhendi, H., \& Wahyu, R 2001. Pengantar Studi Sosiologi Keluarga, Bandung: CV Pustaka Setia.

Tucker, C. E. 2000. Psychological Self Help, Dating, Love, Marriage, and Sex,Clayton Tucker-Ladd \& Mental Health Net, Chapter 10.

Walgito, B. 1984. Bimbingan dan Konseling Perkawinan, Yogyakarta: Yayasan Penerbitan Fakultas Psikologi Universitas Gadjah Mada.

Walton, S.L. 2000, Marital Satisfaction Among African-American Couples, California State University, Stanislaus Journal of Research, Volume 5 Number 1, hal, 4-8.

,2004. Faktor Praperkawinan yang Berpengaruh Pada Sukses Perkawinan, Surat Kabar Harian KOMPAS edisi 11 April 2004.
Internet:

Ali Harharah, F. Bedanya Ta'aruf dan Pacaran,dalam www.mailarchive.com/ ppiindia@yahoogroups.com/msg009 23.html - 12k

Chodron, V.T. Hidup Bahagia Dalam Perkawinan, dalam Bodhi Budhhist Centre.com

Ma'shum, Y. \& Wahyurini, C. Pacaran itu apa sih? Dalam http:Llwww. kompas.com/kesehatan/news 1040 4/11/104645.htm

Shamai, M., \& Lev, R. 1999. Marital Quality Among Couples Living Under The Threat of Forced Relocation: The case of families in the Golan Heights, Jurnal of Marital and Family Therapy, April 1999 dalam Find Articles.com

Agama Bisa Tingkatkan Kualitas Perkawinan. Kompas.com 30 Maret2005 